to consider problems in particular fields of research, and, with the approval of the Commission, ad hoc research committees to deal with special problems.

\section{Grading of Scientific Films}

A memorandum on "The Classification, Appraisal and Grading of Scientific Films" issued by the Scientific Film Association, 34 Soho Square, London, W.1, has been drawn up by the Association after consultation and discussion with interested bodies in Britain and in other countries. It is primarily concerned with films of scientific interest for adult audiences; but the method of appraising and grading recommended should be applicable to all types of documentary films. A specimen card on which it is recommended the content and lay-out of the data concerning each film should be standardized is appended, together with a definition of terms commonly used in a special sense by the film industry and film critics. Notes are included on the synopsis of the content of each film, which should be brief and objective, as well as on the determination of accuracy and comprehensiveness within the terms of reference laid down by the producer and with reference to the purpose of the film, while the grading of the film in relation to the types of audience likely to see it is considered separately. The organisation of the viewing panel, the appraisal group meetings, the appraisal stunding committee and the records to be kept are dealt with in the next section, which includes a specimen viewers' report form. The Association hopes that the principles suggested here will be applied wherever films are appraised. It has earned the gratitude of scientific workers who may need to use such films, as a step towards a standard procedure for film documentation which, if accepted internationally, would be of immense value to all who make or use educational films.

\section{Journal of Glaciology}

The Association for the Study of Snow and Ice, formed in 1936, has grown into the British Glaciological Society, which this year has started the publication of the Journal of Glaciology. There is room for such a publication not only to produce the papers read before the Society itself but also to consider many practical aspects of snow and ice. Without undue overlapping, it is clearly desirable to make contacts with various aspects of geomorphology, meteorology and geography. The Journal (price $7 s .6 d$.) is under an editorial committee consisting of Messrs. G. Seligman, W. L. S. Fleming, B. Roberts and R. Moss, and its present address is care of the Royal Geographical Society, London, S.W.7. The first number has varied contents following an introductory note by Prof. H. W. Ahlmann. Mr. G. Seligman explains Dr. R. Streiff-Becker's theory of extrusion flow in glaciers, and the Rev. W: L. S. Fleming discusses some of the Antarctic glaciological researches of Byrd's Third Antarctic Expedition. There are also a number of short articles and the first instalment of a list of recent glaciological publications, in the main non-polar works. The Journal promises to find a place among scientific periodicals of value.

\section{U.S. Chemical Corps Advisory Committee}

AT the request of Major-General Alden H. Waitt, chief of the U.S. Chemical Corps, an advisory committee has been appointed to serve as a liaison group between the Corps and the chemical profession and industry, and to provide advice on scientific and personnel matters in connexion with Chemical Corps research and development. The committee is as follows : Dr. W. Albert Noyes, jun., president of the American Chemical Society and head of the department of chemistry in the University of Rochester (chairman); Prof. R. Adams, University of Illinois ; Prof. A. C. Cope, Massachusetts Institute of Technol. ogy; Colonel Bradley Dewey, of Cambridge, Mass., formerly U.S. Rubber Administrator; Dr. Willard H. Dow, president and chairman of the Dow Chemical Co., Midland, Mich.; Prof. Vincent du Vigneaud, Cornell University Medical College; Prof. Louis F. Fieser, Harvard University; Dr. Per K. Frolich, co-ordinator of research of Merck \& Company, Rahway, N.J. ; Prof. H. F. Johnstone, University of Illinois; Sidney D. Kirkpatrick, chairman of the American Section of the Society of Chemical Industry; Dr. Walter Kirner, director of the Chemical and Biological Coordination Center of the National Academy of Sciences; Dr. Stanford Moore, Rockefeller Institute for Medical Research; R. L. Murray, vice-president and technical director of the Hooker Electrochemical Co., Niagara Falls, N.Y.; Prof. Charles C. Price, Notre Dame University; Prof. Glenn T. Seaborg, University of California; Prof. Harold C. Weber, Massachusetts Institute of Technology ; and Dr. Robert E. Wilsqn, chairman of the board of directors of the Standard Oil Co. of Indiana.

\section{Chinese Fisheries}

AFter many years of devastation China is now, with the help of the United Nations, endeavouring to bring about the rehabilitation of her basic industries. Not least in importance is the fishing industry, and a Chinese Fisheries Research Institute has been formed for the purpose of carrying out investigations necessary to guide the Chinese fisheries industry during the difficult period of the immediate future and to provide data upon which to base enlightened fisheries administration. Implementation of this programme is severely hampered by lack of books and equipment, and an appeal has been launched for donations of any suitable books, journals and other periodicals that individuals or institutions may be able to spare. As the Institute possesses little more than a measuring-board in the way of equipment, donations of scientific apparatus will also be welcomed. All gifts and offers of help should be sent to the Director, Fisheries Research Institute, Room 402, National City Bank Building, 54 Kiukiang Road, Shanghai, China.

\section{Quality Control Methods in Canada}

A specrar committee has just been established by the National Research Council of Canada to promote the application of mathematical methods in the trieatment of certain industrial production problems. Members of the committee include specialists in statistical quality control procedures, in sampling surveys, in the design of experiments, and in biometry or the statistical study of variation; the chairman is Dr. J. W. Hopkins, National Research Council, Ottawa. The committee will assist Canadian users of mathematical statistical methods by consultation and advice respecting specific technical problems; it will also support research in this field by qualified workers, and provide a means of liaison with technical groups in Canada and abroad. 